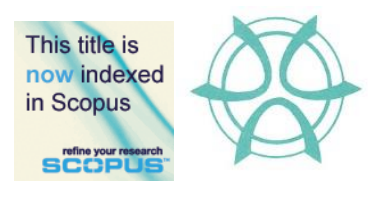

PLANNING MALAYSIA:

Journal of the Malaysian Institute of Planners

VOLUME 17 ISSUE 1 (2019), Page 138 - 148

\title{
FACTORS AFFECTING THE HOUSING PREFERENCES OF HOMEBUYERS IN KUALA LUMPUR
}

\author{
Puvaneswary Thanaraju ${ }^{1}$, Puteri Ameera Mentaza Khan ${ }^{2}$, Nur Hafizah \\ Juhari $^{3}$, Sheelah Sivanathan ${ }^{4}, \&$ Nurhayati Md Khair ${ }^{5}$ \\ ${ }_{1,2,3,4,5}$ Faculty of Building and Property Management \\ UNIVERSITI TUNKU ABDUL RAHMAN
}

\begin{abstract}
The Malaysian Property Market Report 2016 reported that Malaysian properties transactions were down, office occupancies were down, and simultaneously unsold units were up. Almost two thirds of the total homes that developers launched remained unsold, comprising 90,491 units at the end of 2016 including of those completed, under construction, and not constructed. In recent years, the declining phenomenon in the property market is getting worse apparently. The reason behind this situation is mainly due to the rising cost of living which causes the purchasing power to be weakened; therefore, to buy a property or even goods for daily use has become difficult as the overall spending power of the Malaysians has decreased. Determining the important factors that impact upon the decision making of the house purchasing process could develop a better understanding for both buyers and home providers which eventually could avoid the 'unsold' properties scenario in the market. Hence, the objective of this research is to evaluate the relationship between the three main factors identified which are financial, location, and neighbourhood towards the housing preferences of homebuyers in Kuala Lumpur. A total of 100 respondents, ranged between 25 to 34 years old, responded to the survey, and the results were derived using the multiple regression analysis. The results favour the locational factors that contribute significantly to the determination of a buyer's preferences when purchasing a house.
\end{abstract}

Keywords: housing, housing preferences, homebuyer in Kuala Lumpur 


\section{INTRODUCTION}

In Malaysia, residential housing is the dominant properties in the real estate market. It recorded the highest percentage of $65.2 \%$ of the overall real estate market. Johor, Pulau Pinang, and Kuala Lumpur are the dominant states in residential properties with $20.4 \%, 16.9 \%$, and $8.3 \%$ shares of the market, respectively. The Property Market Report (PMR) in 2015 revealed that the property market performance slowed down by a marginal $5.7 \%$ in volume and $8.0 \%$ in value of the overall performance property market in 2014 . In 2015 , there were 70,273 housing units launched compared to 68,351 housing units in 2014 . On the other hand, the unsold housing units for 2015 were 41,184 units $(58.6 \%)$ compared to 47,506 units $(54.61 \%)$ in 2014 . Thus, the residential property showed retardation in the overall performance, and $58.6 \%$ of the launched units remained unsold in 2015 .

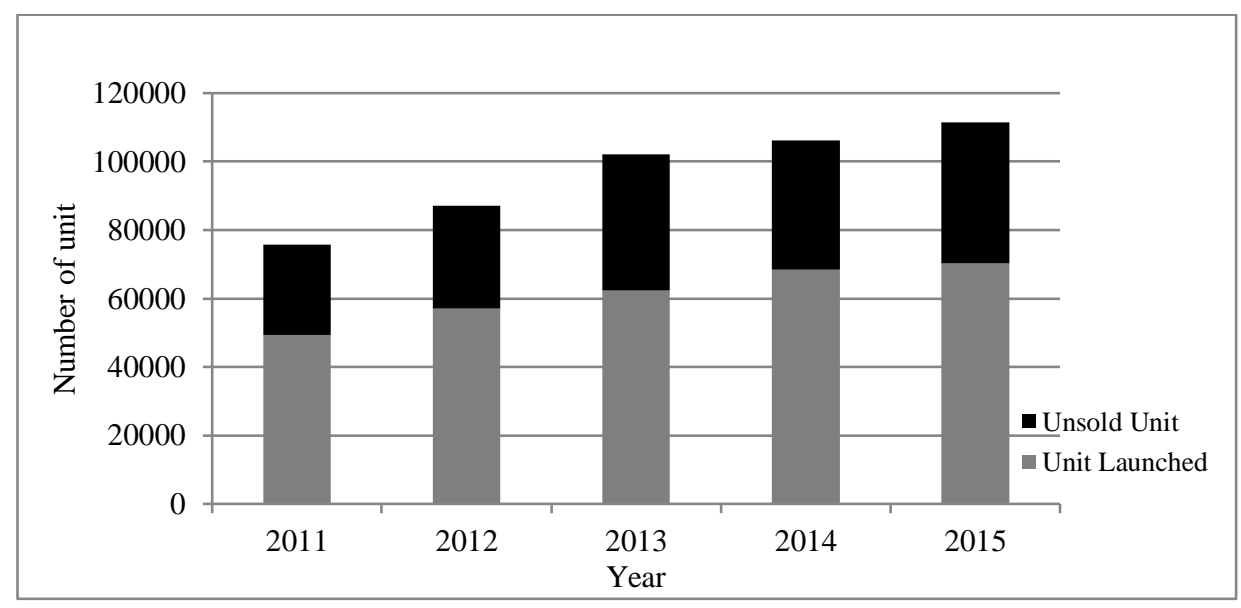

Figure 1: Launched and unsold units in Malaysia Source: JPPH (2011-2015)

Besides, the total number of residential properties transacted in Malaysia decreased in 2015 compared to 2012 from 272,669 to 235,967 units based on the Property Market Report. It also stated that from 2013 to 2015, the unsold units did increase significantly from 9,361 units to 31,261 units in the total numbers. The sold units in Kuala Lumpur had decreased from 40,522 units in 2014 to 33,781 units beginning of 2015 and continued to decrease significantly towards the end of 2015. Residential property transactions per year in Kuala Lumpur faced a similar situation where it decreased from 24,314 in 2011 to 10,606 in 2013 (JPPH, 2015). The declining transactions may result due to various reasons, but the overall scenario showed that the people in Kuala Lumpur paid less focus on the process of selling and buying properties within this period. 
Puvaneswary Thanaraju, Puteri Ameera Mentaza Khan, Nur Hafizah Juhari, Sheelah Sivanathan, \& Nurhayati Md Khair Factors Affecting the Housing Preferences of Homebuyers in Kuala Lumpur

The homebuyers' preferences are strongly affected by some factors which eventually leads to the decision making of purchasing a housing unit (Komurlu, Gurgun, \& Arditi, 2013). The housing unit that the developer offered to the homebuyers did not meet their preferences and needs has become one of the main factors that caused the launched housing units to remain unsold. According to Petrus (2012), it is a competitive residential property market in Malaysia because most of the residential property developers in Malaysia are utilising the sell-then-build concept. The homebuyers can only make a judgement based on the layout plan and description of the property to imagine how their future property will look alike. These will lead to some difficulties in the decision making to purchase property as they need to rely on many contributing factors to decide on the purchase such as type, location, and price. Thus, this paper highlighted the most critical contributing factors in the preferences of a homebuyer in deciding to purchase a house in Kuala Lumpur.

\section{HOUSING PREFERENCES}

Housing preferences are the word forms of the housing quantitative and qualitative features that the residents would prefer to have for their home. Preference housing is distinguished into two related terms, which are housing expectation and housing aspiration. Housing aspiration is the desire for housing or standard-oriented towards the future, whereas expectation indicates the realistic assessment of future housing conditions (Morris \& Winter, 1978).

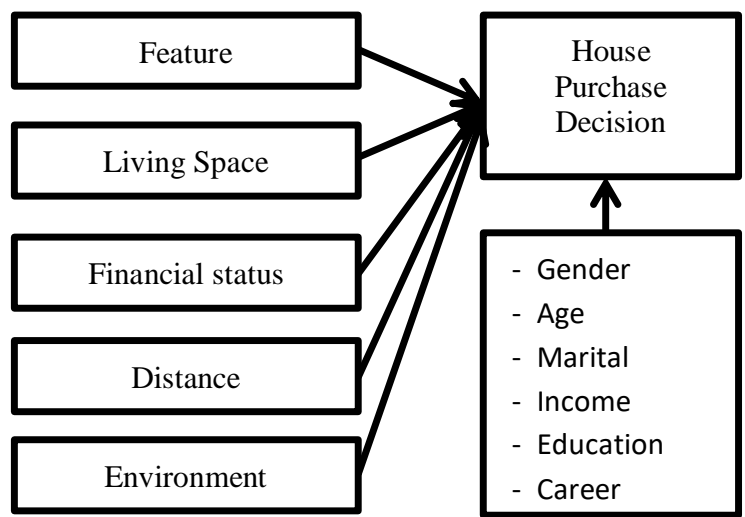

Figure 2: Determinants of homeownership conceptual model Source: $\mathrm{Si}$ (2012)

Si (2012) highlighted the five factors that affect the house purchasing decision which are the feature, living space, financial status, distance, and environment, as shown in Figure 2 above. Meanwhile, Abdullah, Nor, Jumadi, and Arshad (2012) considered that the seven factors that can affect housing purchase are financial or economics, location, neighbourhood, developer's 
reputation, interior design and space, family life cycle, and exterior design, as shown in Table 1 below. This research only considered three of the factors, namely, financial, location, and neighbourhood.

Figure 3: House Purchasing Considerations Conceptual Model

\begin{tabular}{|c|c|}
\hline Factor 1: Financial/economics & $\begin{array}{l}\text { Price of house } \\
\text { Capability to obtain financing } \\
\text { Term of payment }\end{array}$ \\
\hline Factor 2: Location & $\begin{array}{l}\text { Proximity to workplace } \\
\text { Proximity to amenities } \\
\text { Proximity to town centre } \\
\text { Proximity to main road, highway, public } \\
\text { transport }\end{array}$ \\
\hline Factor 3: Neighbourhood & $\begin{array}{l}\text { Quiet place } \\
\text { Green surrounding } \\
\text { Low crime area }\end{array}$ \\
\hline Factor 4: Developer's reputation & Reputable developer \\
\hline Factor 5: Interior design and space & $\begin{array}{l}\text { Size of the building } \\
\text { Number of floors } \\
\text { Building layout design } \\
\text { Number of bedrooms and bathrooms } \\
\text { Type and quality of finishing }\end{array}$ \\
\hline Factor 6: Family Life Cycle & $\begin{array}{l}\text { Current house too small } \\
\text { Marriage, family expansion }\end{array}$ \\
\hline Factor 7: Exterior design & $\begin{array}{l}\text { Size of garden } \\
\text { Building orientation }\end{array}$ \\
\hline
\end{tabular}

\section{FINANCIAL STATUS}

People's demand on the housing ownership is fundamentally determined by the growth of population and formation rate of household, the price of a house, and the growth of income (Flavin, 2002). The continuous increase in house prices has been an issue among Malaysians. A debate on this issue has been stimulated on the reasons, the suggestions, and the budgeted level for the clear majority of the population. The increase in mortgage borrowing that is encouraged by the rise of house price and a low-interest rate allows consumers to spend which is supported by the increase in their income (Hashim, 2010). In normal cases, 30\% of a household income is spent on housing (Bujang, 2006). In accordance with the study of the ability to purchase a house, income level is an important factor. Income level determined the ability of a household to purchase affordable housing. Thus, the price and category of houses that are affordable for a household are decided by their income level (Bujang, Zarin, \& Jumadi, 2010).

Other than house price and household income, another factor is the ability to afford the housing finance which referred to the financial loans from banks and 
Puvaneswary Thanaraju, Puteri Ameera Mentaza Khan, Nur Hafizah Juhari, Sheelah Sivanathan, \& Nurhayati Md Khair Factors Affecting the Housing Preferences of Homebuyers in Kuala Lumpur

government agencies providing loans (Tuccillo \& Goodman, 1983). Financing is also defined as a long-term loan with a specific period for the purchasing of a house. The financing loans are provided by the financial institutions to individuals who purchase a house from a developer who has a commitment with the bank (Bujang et al., 2010).

\section{LOCATION}

The location of a residential property is another key factor that can affect the homebuyers' housing preferences in Kuala Lumpur. The better the location of a housing project, the more it can generate a higher profit and return to the developer. According to Salleh (2015), location is the main consideration and plays a key role that affects the success of the housing project. A strategic location of a housing project will bring a higher degree of profit and return to the developer. However, a non-strategic location of a housing property may generate lower income and return compared to the housing project with a strategic location. The decision on the location when purchasing a housing property is vital because the house selection will lead to long-term financial burdens to the homebuyers (Litman, 2010). Sean and Teck-Hong (2014) stated that a good location of the residential property could be defined as a residential area with better access to community amenities and facilities. According to Karsten (2010), the distance from their workplace is the main consideration for homebuyers in Malaysia. Traffic jam is the main issue in Kuala Lumpur, and the travelling distance between their workplace and home is their main consideration in purchasing a housing property.

The price and value of the residential property are also affected by the locational factors of a housing project (Elder \& Zumpano, 1991). The price of land and house or residential property is higher if the residential property is in strategic location or area that is near to local amenities such as shopping centres, schools, and public transports. Most of the homebuyers will choose their house near to some amenities. On the other hand, the price of the residential property which is located at a suburban area will be lower than the residential property located at an urban area as the distance from schools, shops, shopping malls, and public transports is far from the residential property. A research done by Aluko (2011) showed that the influence of location in the housing market is very significant and strongly affect the homebuyers' decision when purchasing a residential property.

According to Kane, Riegg and Staiger (2006), good quality of school means a quality neighbourhood and a great school area contributes a positive impact on the neighbourhood. Homebuyers with children consider a neighbourhood with school when purchasing property (Komurlu et al., 2013). 
PLANNING MALAYSIA

Journal of the Malaysia Institute of Planners (2019)

\section{NEIGHBOURHOOD}

Neighbourhood plays a vital role in the housing preferences for a homebuyer. According to Teck-Hong (2011), a good neighbourhood will affect the residential price. Obviously, a good neighbourhood brings a positive impact on the residential price. Based on the survey done by Aluko (2011), the neighbourhood factors are important and are linked to the housing purchase decision. The safety of a neighbourhood is also considered as another aspect during the selection of property. The level of cleanliness and safety are the main considerations of homebuyers (Chapman, 2006). Low quality of cleanliness and safety will bring down the surrounding housing's price and image. The demand for gated and guarded properties has increased in the recent year, especially in Kuala Lumpur because of the community facilities and security. The gated and guarded community facilities show status and symbol that their property is protected (Teck-Hong, 2011). As a result, most of the homebuyers will select the residential property with gated and guarded community facilities.

The most important factors associated with housing preferences are satisfaction with social contacts within the neighbourhood and lack of concern over encountering unfamiliar faces. It reflects the importance of the residents' feeling of having a supportive broader community of known or familiar social contacts (Buys, 2012). Families are actively creating a network of linked lives within their diverse urban environment. These networks can be specified as demographic characteristics, class position, and ideas about a 'good' family life which will affect the housing preferences in the neighbourhood (Karsten, 2007). Zheng (2011) stated that the preferences of future homebuyers would inspire the landscape design of future houses. As a result, the homebuyers with a greater awareness of nature will prefer a more natural-designed landscape when they purchase a house (Daniel, 2001). Furthermore, there have been a few studies that indicate that a property will be sold at a better value if it is located in a quieter neighbourhood. The house price of a noisier location is $30 \%$ lower than the market price compared to the house located in a quiet location (Wilhelmsson, 2000). Traffic noise has always been an issue among homebuyers. A study by Becker and Lavee (2003) stated that there is a $1.4 \%$ and $2.4 \%$ drop in property values in urban and suburban areas respectively.

\section{CONCEPTUAL FRAMEWORK}

In terms of the locational factors, public infrastructure nearby will also increase the value of the property. According to Kaynak and Stevenson (1982), the locational factor is one of the essential factors that affect an individual's decision in purchasing a house. The neighbourhood factors are also very important in a housing purchase consideration. The safety of a neighbourhood, such as whether there is a high crime rate in the area, will affect the buyer's decision. The level of pollutants such as the cleanliness of the residential area or river nearby is 
important too. It is confirmed that the environment has a big influence on housing buyer (Al-Nahdi \& Ghazzawi, 2015). Financial factors such as the price of the property, amount of loan that the purchaser will be able to borrow from the bank, and also the duration of the mortgage loan that the buyer has to pay, as well as the payment term will also greatly affect the decision of the buyer when they are purchasing property. Financial status is much more relevant to homebuyers' housing preferences (Combs \& Hinkle, 1987).

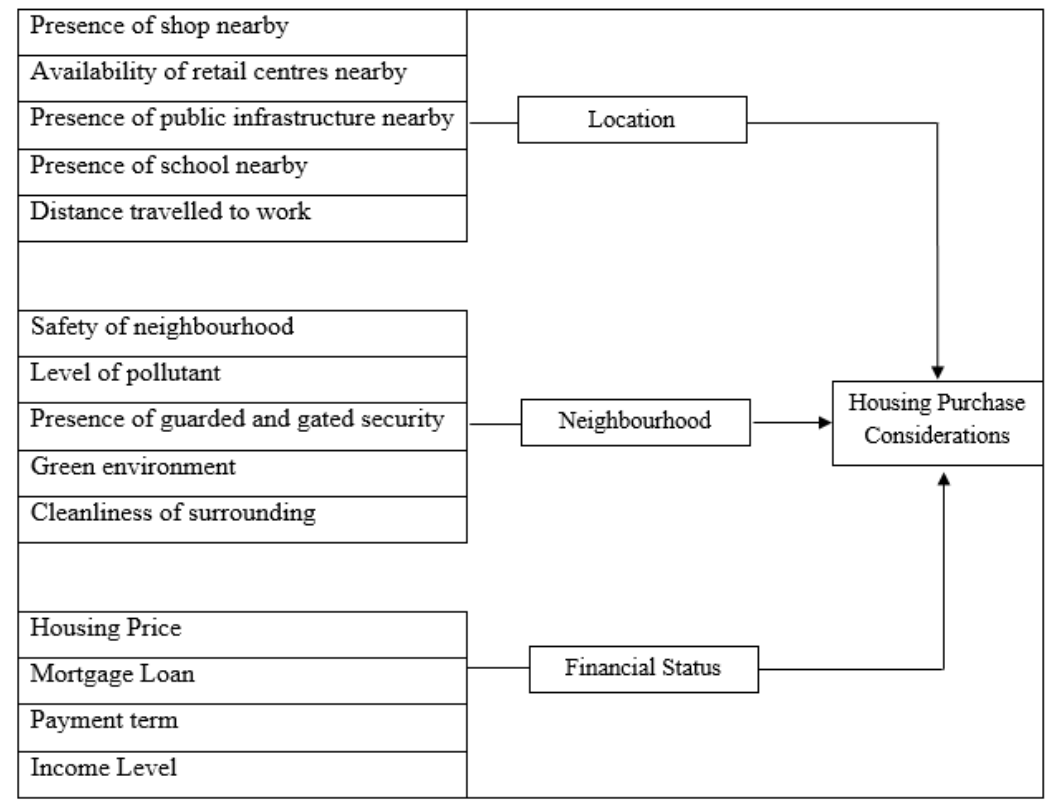

Figure 3: Factors affecting housing preferences among homebuyers

\section{METHODOLOGY}

The quantitative research was utilised for this study whereby 150 questionnaires were distributed to respondents, and 100 questionnaires which were answered without error were collected to be analysed. The area for questionnaire distribution was focused in Kuala Lumpur among homebuyers aged 25 to 34 years old. Purposive sampling was used and the information obtained were analysed through SPSS and presented below.

\section{RESULTS}

The survey undertaken among the homebuyers in Kuala Lumpur revealed that somehow all the factors have a significant relationship with the preferences and the decision-making process of home buying. 
PLANNING MALAYSIA

Journal of the Malaysia Institute of Planners (2019)

Table 2: Multiple regression analysis

\begin{tabular}{ccccc}
\hline $\begin{array}{c}\text { Dependent } \\
\text { Variable }\end{array}$ & Independent Variables & $\begin{array}{c}\text { Coefficient } \\
\text { Value (B) }\end{array}$ & $\begin{array}{c}\text { Significant } \\
\text { Value (Sig.) }\end{array}$ & $\begin{array}{c}\text { Accepted/ } \\
\text { Rejected }\end{array}$ \\
\hline Housing & Financial Factors & .200 & .054 & Rejected \\
Preferences & $\begin{array}{c}\text { Locational Factors } \\
\text { Neighbourhood } \\
\text { Factors }\end{array}$ & .435 & .000 & Accepted \\
& -.098 & .362 & Rejected \\
\hline
\end{tabular}

The results show that there is no significant relationship between the housing purchase consideration and financial status of the buyer. Based on the inferential analysis result, it shows a positive relationship between financial status and housing preferences of homebuyer in Kuala Lumpur (0.200). The value of significance for financial factors is 0.054 , which is more than the $\mathrm{P}$ value of 0.05 .

In contrast to the results of this study, according to Bujang et al.(2010), income level has significantly contributed to the housing market. However, the study says that the relationship between income level and housing affordability that affect the local market is still not clear and needs to be reviewed. Theoretically, interest determined the purchasing of a residential unit. Price, location, and the population's socio-economic environment are the essential factors influencing the homebuyers housing preferences (Rossi, 1955).

The study found that there is a significant relationship between housing purchase considerations and locational factors. The inferential analysis shows a positive relationship between the locational factors and housing preferences of homebuyer in Kuala Lumpur (0.435). The value of significance for financial factors is 0.000 , which is less than the $\mathrm{P}$ value of 0.05 . The importance of consumer housing and location preferences as a factor in urban development patterns is increased. Homebuyers will be more likely to select a residential location that is closer to their workplace, and it will affect the household purchase decision (Jordan, Birkin, \& Evans, 2012). Moreover, for married homebuyers, they tend to reside at location selected primarily for proximity to the husband's best job. Homebuyers will also select their housing choice closer to their community such as friends and location that ease their religious prayer (Madden, 1981). In addition, for families with children, a residential location close to the school will be taken into consideration. Homebuyers will also prefer property located near to public infrastructure such as the LRT, highway, bus terminal, and others. Hence, the distance to infrastructure is an important factor in choosing a property for homebuyers too. Also, accessibility to shopping malls and retail shops will also affect the homebuyers in choosing the property.

The results of analysis shows that there is no significant relationship between housing purchase considerations and neighbourhood factors. Based on the inferential analysis result generated, it shows a negative relationship between neighbourhood factors and housing preferences of homebuyers in Kuala Lumpur 
Puvaneswary Thanaraju, Puteri Ameera Mentaza Khan, Nur Hafizah Juhari, Sheelah Sivanathan, \& Nurhayati Md Khair Factors Affecting the Housing Preferences of Homebuyers in Kuala Lumpur

with a correlation coefficient of -0.098 . The value of significance for neighbourhood factors is 0.362 , which is more than the $\mathrm{P}$ value of 0.05 . Homebuyers will consider neighbourhood factors such as safety, the noise of surrounding, green environment, level of pollutants, and the presence of gated and guarded security before choosing their house of choice. The prime consideration that affects the homebuyers among the neighbourhood factors is safety (Quigley, 1985). Theoretically, a quiet and secure neighbourhood will be preferred by homebuyers. The safety of a neighbourhood becomes a major concern among most of the homebuyers as the crime rates are increasing in Kuala Lumpur (Mohit \& Elsawahli, 2010). Homebuyers are also willing to pay more for a quality neighbourhood, and thus enjoy a safer environment (Lang \& LeFurgy, 2007). In addition, homebuyers will also take into consideration the availability of facilities including retail shops and restaurants nearby, medical services, police station, and other facilities.

\section{CONCLUSION}

Location is the only factor that shows a significant relationship with the housing purchase considerations. This outcome is because Kuala Lumpur is considered to be the best option to work as it is located at the centre point. This reason indicates the importance of strategic locations such as close to workplace, schools and nurseries, as well as easy accessibility, are strongly attached to the daily life of people in Kuala Lumpur. Therefore, homebuyers will consider the locational factors prior to purchasing a house to ensure that they are investing in a suitable location for their stay rather than emphasising too much on the financial and neighbourhood factors.

\section{REFERENCES}

Abdullah, S. L., Nor, S. I., Jumadi, S. N., \& Arshad, S. H. (2012, April). First-time home buyers: Factors influencing decision making. 2012 International Conference on Innovation and Technology for Sustainable Built Environment. April 23-24, 2012, Perak, Malaysia.

Al-Nahdi, T. S., \& Ghazzawi, O. H. (2015). Behavioral factors affecting real estate purchasing. International Journal of Business and Social Science, 6(8), 146-154.

Aluko, O. (2011). The effects of location and neighbourhood attributes on housing values in Metropolitan Lagos. Ethiopian Journal of Environmental Studies and Management, 4(2), 69-82.

Becker, N., \& Lavee, D. (2003). The benefits and costs of noise reduction. Journal of Environmental Planning and Management, 46(1), 97-111.

Bujang, A. A. (2006). Faktor-faktor yang mempengaruhi penetapan perbezaan harga rumah kos rendah, sederhana rendah dan sederhana. Skudai: Universiti Teknologi Malaysia

Bujang, D. A., Zarin, H. A., \& Jumadi, N. (2010). The relationship between demographic factors and housing affordability. Malaysian Journal of Real Estate, 5(1), 5057. 
Buys, L. (2012). Residential satisfaction in inner urban higher-density Brisbane, Australia: role of dwelling design, neighbourhood and neighbours. Journal of Environmental Planning and Management, 55(3), 319-338.

Chapman, D. W. (2006). Determinants of neighborhood satisfaction in fee-based gated and nongated communities. Urban Affairs Review, 41(6), 769-799.

Combs, E. R., \& Hinkle, T. F. (1987). Managerial behaviour of home buyers. Journal of Consumer Studies \& Home Economics, 11(4), 375-386.

Daniel, T. (2001). Aesthetic preference and ecological sustainability. In T. Daniel (Ed.), Forests and landscape: Linking ecology, sustainability and aesthetics (pp. 1529). Wallingford: CABI Publishing.

Elder, H. W., \& Zumpano, L. V. (1991). Tenure choice, housing demand, and residential location. Journal of Real Estate Research, American Real Estate Society, 6(3), $341-356$

Flavin, M. (2002). Owner-occupied housing and the composition of the household portfolio. The American Economic Review, 92(1), 345-362.

Hashim, Z. A. (2010). House price and affordability in housing in Malaysia. Akademika, $78,37-46$.

Jabatan Penilaian dan Perkhidmatan Harta [JPPH] (2015). Property Market Report (20112015). Putrajaya: Ministry of Finance Malaysia.

Jordan, R., Birkin M., \& Evans A. (2012). Agent-based modelling of residential mobility, housing choice and regeneration. In A. Heppenstall, A. Crooks, L. See, \& M. Batty. (Eds), Agent-Based Models of Geographical Systems (pp.511-523). Dordrecht: Springer.

Kane, T. J., Riegg, S. K., \& Staiger, D. O. (2006). School quality, neighborhoods, and housing prices. American Law and Economics Review, 8(2), 183-212

Karsten, L. (2007). Housing as a way of life: Towards an understanding of middle-class families' preferences for an urban residential location. Housing Studies, 22(1), 83-98.

Karsten, L. (2010). Housing as a way of life: Towards an understanding of middle-class families' preferences for an urban residential location. In Urban Studies - Society (pp. 357-372). Thousand Oaks: Sage Publications.

Kaynak, E., \& Stevenson, L. (1982). Comparative study of home buying behaviour of Atlantic Canadians. Management Research News, 5(1), 3-11.

Komurlu, R., Gurgun, A. P., \& Arditi, D. (2013). Drivers of residential developers' marketing strategies based on buyer preferences. METU Journal of the Faculty of Architecture, 3(2), 1-16.

Lang, R. E., \& LeFurgy, J. B. (2007). Boomburbs: The rise of America's accidental cities. Washington, DC: Brookings Institution Press.

Lip Sean, S., \& Teck Hong, T. (2014). Factors affecting the purchase decision of investors in the residential property market in Malaysia. Journal of Surveying, Construction and Property, 5(2), 1-13.

Litman, T. (2010). Where we want to be: Home location preferences and their implications for smart growth. Victoria, Canada: Victoria Transport Policy Institute. 
Puvaneswary Thanaraju, Puteri Ameera Mentaza Khan, Nur Hafizah Juhari, Sheelah Sivanathan, \& Nurhayati Md Khair Factors Affecting the Housing Preferences of Homebuyers in Kuala Lumpur

Mohit, M. A., \& Elsawahli, H. M. (2010). Crime and housing in Malaysia: Case study of Taman Melati terrace housing in Kuala Lumpur. Asian Journal of EnvironmentBehaviour Studies, 1(3), 26-35.

Madden, J. F. (1981). Why women work closer to home. Urban Studies, 18(2), 181-194.

Morris, E., \& Winter, M. (1978). Housing, family, and society. Hoboken, NJ: John Wiley \& Sons.

Petrus, V. (2012). Study on the key factors influencing buyers' preferences for house purchase in Kota Kinabalu (Master's thesis), Universiti Malaysia Sabah, Malaysia.

Quigley, J. M. (1985). Consumer choice of dwelling, neighborhood and public services. Regional Science and Urban Economics, 15, 41-63.

Rossi, P. (1955). Why families move. London: Sage Publications.

Lang, R. E., \& LeFurgy, J. B. (2007). Boomburbs: The rise of America's accidental cities. Washington, DC: Brookings Institution Press.

Salleh, N. A. (2015). Influencing factors of property buyer in hillside residential development. Procedia - Social and Behavioral Sciences, 170, 586-595.

Si, P. T. (2012). Key factors affecting house purchase decision of customers in Vietnam (Master's thesis). University of Economics Ho Chi Minh City, Vietnam.

Teck-Hong, T. (2011). Neighborhood preferences of house buyers: the case of Klang Valley, Malaysia. International Journal of Housing Markets and Analysis, 4(1), 58-69.

Tuccillo, J. A., \& Goodman, J. L. (1983). Housing finance: A changing system in the Reagan era. (n.p.): Urban Institute Press.

Wilhelmsson, M. (2000). The impact of traffic noise on the values of single-family houses. Journal of Environmental Planning and Management, 43(6), 799-815.

Zheng, B. Z. (2011). Preference to home landscape: wildness or neatness? Landscape and Urban Planning, 99(1), 1-8

Received: $28^{\text {th }}$ October 2018. Accepted: $1^{\text {st }}$ March 2019 